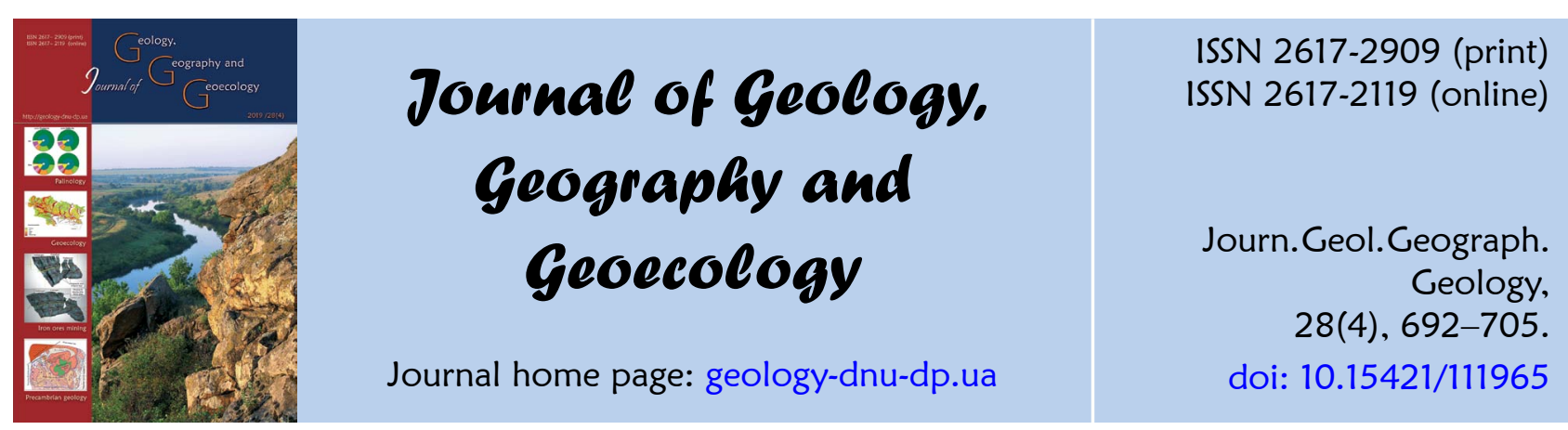

Olha A. Lyubitseva, Galina M. Zavarika

Journ. Geol. Geograph. Geoecology, 28(4), 692-705.

\title{
Geographic analysis of the condition of tourism of Luhansk region (Ukraine) in the context of the conflict
}

\author{
Olha A. Lyubitseva ${ }^{1}$, Galina M. Zavarika ${ }^{2}$ \\ ${ }^{1}$ Taras Shevchenko National University of Kyiv, Ukraine \\ ${ }^{2}$ Volodymyr Dahl East Ukrainian National University, Sievierodonetsk, Dgalina_10@ukr.net
}

Received: 17.02.2019

Received in revised form: 04.03.2019

Accepted: 20.09.2019

Annotation.The article is devoted to the geographic analysis and evaluation of the development of tourism in Luhansk region in the context of the current conflict. The aim of this report is to monitor the state of tourism in Luhansk region, which is especially relevant in this transformational period. We used research methodology which combines the philosophical and general scientific principles that form the methodological principles of scientific research and include a number of laws and categories. Analytical, statistical, comparative-geographical, historical methods of research were used. We considered in chronological order the formation of tourism in the region. The state of tourism in the region under the conditions of the conflict is analyzed. It is revealed that the current state of tourism is that of crisis, but there are positive prospects for development. The geographical possibilities of tourism development at the present stage are substantiated. It is proposed to develop the most promising types of tourism. The scientific novelty is due to choice of theme itself, because geographers devote insufficient attention to the study of tourism development issues in the context of the conflict. For the first time, a geographic analysis of the status of tourism of Luhansk region in the conditions of the conflict is presented. The methods of comprehensive assessment of tourism development at the regional level have been improved with the use of quantitative and qualitative indicators, which allows us to determine the directions of tourist development in the region. The existing information on the influence of the conflict period on tourism development is supplemented.For the first time, a comprehensive analysis of the status of tourism in Luhansk region was carried out for different periods: at the beginning of the conflict and during the conflict, which showed that Ukraine's image as a place of conflict led to the emergence of new social-geographical features of the development of tourism in the east of Ukraine. It is revealed that the conflict has led to instability in the development of tourism, tourists who are worried about their safety refuse to visit a conflicted country or region. This inevitably leads to a decrease in the number of international tourist arrivals and revenues from tourism, a decrease in the number of objects of tourism and of collective accommodation facilities. It is determined that the attractiveness for tourism and image of the eastern region is almost lost as a result of the conflict. It is proved that the conflict negatively impacted the development of the tourism industry in the region, namely, all types of tourism suffered, significantly reducing the total number of tourists.It is determined that tourism in the post-conflict period may become a promising direction of economic development of the eastern regions of Ukraine. The main provisions, factual material and conclusions of the article can be used for further research on the development of tourism in Luhansk region and the creation of a concept for overcoming the negative consequences of the conflict of 2014-2019 in Ukraine for the development of the national tourism industry.

Keywords: tourism, analysis, geography, conflict, post-conflict, tourist flows.

\section{Географічний аналіз стану туризму Луганської області (Україна) в умовах конфлікту}

\author{
О. О. Любіцева ${ }^{1}$, Г. М. Заваріка ${ }^{2}$
}

\section{${ }^{1}$ Київський національний університет імені Тараса Шевченка \\ ${ }^{2}$ Східноукраӥнський національний університет імені Володимира Даля, Сєвєродонецьк, Dgalina_10@ukr.net}

Анотація. Стаття присвячена географічному аналізу та оцінці розвитку туризму в Луганській області в умовах конфлікту. Метою цієї роботи є моніторинг стану туризму в Луганській області, що особливо актуально в цей трансформаційний період. Використоно аналітичний, статистичний, порівняльно-географічний, історичний методи дослідження. Розглянуто хронологічний порядок формування туризму в регіоні. Проаналізовано стан туризму в регіоні в умовах конфлікту. Виявлено, що нинішній стан туризму є кризовим, але $є$ позитивні перспективи розвитку. Обгрунтовано географічні можливості розвитку туризму на сучасному етапі. Запропоновано розвивати найбільш перспективні види туризму. Наукова новизна обумовлена 
самою темою, оскільки географи приділяють недостатню увагу дослідженню питань розвитку туризму в контексті конфлікту. Вперше представлений географічний аналіз туристичного статусу Луганської області в умовах конфлікту. Методи комплексної оцінки розвитку туризму на регіональному рівні були покращені з використанням кількісних і якісних показників, що дозволяє визначити напрями для туристів регіону. Доповнено інформацію про вплив конфліктного періоду на розвиток туризму.Вперше комплексний аналіз туризму Луганської області було проведено в різний час: на початку конфлікту і в контексті конфлікту, який показав, що знаходження України у стані конфлікту призвело до появи нових соціально-географічних особливостей розвитку туризму на сході України. Виявлено, що конфлікт призводить до нестабільності в розвитку туризму, туристи турбуються про свою безпеку, відмовляючись відвідувати країну або регіон. Це неминуче веде до зниження числа міжнародних туристських прибуттів і надходжень від туризму, зменшення кількості туристичних об'єктів і об'єктів колективного розміщення. Визначено, що в результаті конфлікту туристична привабливість і імідж східного регіону практично втрачені.Визначено, що туризм у постконфліктний період може стати перспективним напрямком економічного розвитку східних регіонів України. Основні положення, фактичний матеріал та висновки статті можуть бути використані для подальших досліджень 3 питань розвитку туризму в Луганській області та створення концепції щодо подолання негативних наслідків конфлікту у 2014-2019 роках в Україні для розвитку вітчизняної туристичної галузі.

Ключові слова: туризм, аналіз, географія, конфлікт, постконфліктний, туристичні потоки.

Introduction. The problems of sustainable tourism development, which include conflicts and possible risks, have been considered using the special foreign and domestic literature. These are works of S. Huntington, O. Spengler, A. Toynbee, I. Vynnychenko, O. Beidyk, A. Oleksandrovoy, O. Lyubitseva and O. Travina.

In studies of international scientists, there is no consensus about the definition of "conflict". The variety of interpretations is determined by the ambiguous understanding of the nature of this phenomenon.

The only thing which we can guarantee: it is inherent in all aspects of social life. Such a situation has inevitably stimulated interest in the issue of conflict in the professional literature, especially among foreign scientists.

As per R. Dahrendorff, the author of the conflict model of society, the main question in conflicts is who and in what form commands the resources, in whose hands is the power which allows one group of people to direct the activities of others (Dahrendorff, 2002).

For the initial classification of conflicts, the American researcher M. Kaldor thought it was enough to compare new wars with previous ones according to programme goals, methods of fighting, as well as ways of financing them (Kaldor, 2001).

Huntington argued that there will not be a "universal civilization" in the world; individual civilizations will continue to exist, and the success of international relations will depend on how these civilizations will coexist with one another. According to the researcher, being a "modern" civilization does not necessarily mean being a "Western" civilization, and therefore the West must take into account the persistent attempts of non-Western societies to modernize and, at the same time, not "westernize". The value of the concept of S. Huntington is based in the fact that he drew the attention of politicians, researchers, journalists to the problem of cultures and civilizations as participants in the world historical process. Huntington's work is an invaluable material for understanding the political processes of our time. The researcher's recommendations for avoiding conflicts deserve attention and discussion (Huntington, 1996).

Spengler's concept consists in the allocation of cultural worlds that have an identical life cycle that resembles the body's life cycle: origin, growth, development, decay and death. Each phase in any culture ,according to Spengler, automatically passes into the next as soon as its time comes. In his opinion, each culture is a "living organism" and has its own history. He denied the existence of universal culture, arguing that world history consists of the history of eight large cultures, each locked in its own development.Each culture, according to the scientist, has its destiny and lives about $1000-1500$ years. Then the culture dies and traces of it remain in the form of civilization. The concept of fate is fundamental to the O. Spengler's philosophy of culture. O. Spengler realized the threat to world history in overly rationalized and highly pragmatised activity of people (Spengler, 1998).

A. Toynbee sharply criticized western civilization for the loss of spirituality and the excessive development of mercantile interests and consumer psychology. Unbridled industrialization and the arms race, according to the scientist, will lead to an aggravation of the ecological crisis and intensification of the struggle for raw materials. Industrialized countries will face the hostile position of technically backward countries, which inevitably will end in a global conflict, and will eventually lead to economic decay. The concept of A. Toynbee is also interesting because it contains quite clearly formulated criteria for defining civilizational identity. He terms them religion, history, language, customs and culture. A. Toynbee attaches particular importance to religion, which he considers "one way and one direction in comparison with the diverse and repetitive history of civilizations" (Toynbee, 1996). 
Tourism in Lugansk region officially began to develop after the adoption of the Decree No. 743 of November 29, 2002 "On Approval of the Tourism Development Program in Luhansk region of 20022010" (The programme of tourism development in Lugansk region of 2002-2010, 2002).

During this period, the status of tourism in Luhansk region was considered as stable when the number of tourist organizations began to grow at a high rate, and in crisis when the volume of tourism services fell due to the reduction of the material base in the field of tourism and the existence of conflict.

In the last few pre-conflict years, tourism began to play a prominent role in the life of eastern Ukraine. Tourism in Luhansk region has developed in several directions: medical-improvement tourism, sport tourism, religious and industrial tourism. However, the conflict situation did not allow for their development to the appropriate extent.

Thus, the dynamic changes in the economic and geographical situation of Luhansk region at this stage require further development of these issues.

Problem formulation. A great deal of work is devoted to the study of tourism in the context of conflict in the world and in Ukraine by the following authors : Averina A., Aziz Kh., Baidyk O., Drakos K., Zavarika G., Zelenko O., Tkachuk L. and others. Most of these authors describe aspects of the impact of conflict situations on tourism activities.

Thus, the Russian philosopher A. Averin, while investigating the issues of state regulation of demographic and migration processes, notes that migration can be caused by political, economic, social and spiritual processes. Reasons may include military, national, ethnic, religious conflicts, terrorism, environmental and climatic factors (Averin, 2017).

There is no doubting the conclusions of O. Beidik, N. Koroma and S. Syrovets, who argue that armed conflicts of various size and sterngth always have a proportional "effect" on the development of tourism, which consists in reducing the image of the country, destroying the tourist infrastructure and leading to destruction in historical and natural heritage (Beidik et. al 2016a).

The author agrees with the opinion of L. Tkachuk that the tourism sector faces serious challenges due to the serious political instability which is growing rapidly and that the flow of tourists to the country has declined because of the negative image the country has acquired (Tkachuk, 2016 a).

During the pre-conflict period, the tourist possibilities of the region were investigated by the following Ukrainian researchers: O. Lyubitseva,
V.Zaleshchik, G. Myshechkin, A. Anosov, G. Sorokin. They emphasized the necessity of using and developing the tourism sector.Thus, O. Lyubitseva and V.Zaleshchyk investigated the recreational and tourist zoning of Lugansk region and established the tourist opportunities of the territory (Liubitseva, Zaleschik, 2012). G. Mishechkin and O Anosova analyzed the tourism and recreational potential of the Donbas and argued for the prospect of its development despite the existing problems (Myshechkin, Anosova, 2013).

A feature of Luhansk region is the insignificant development of its tourism sector during the preconflict period, which makes it difficult to prove the feasibility of restoring tourism activity. Perhaps this explains the small number of publications on tourism in the region over the past four years. The author of the publication investigated tourism in the region both in pre-conflict and conflict periods and emphasized the possibilities of tourism development there (Zavarika, 2016a).

O. Zelenko mentioned that prospects of tourism development in Luhansk region in the conditions of military-political instability, the author noted that various types of tourism have the right to exist and emphasized the necessity of development of tourism in the region, including rural green, medical-health, religious, industrial tourism (Zelenko, 2015a).

The tourism sphere can affect to development of the region. Ukraine has not enough experience in restoring tourist activity after armed conflict, therefore, the developing of both theoretical and practical, challenges is a new issue in public geography. Thus, the issue of analyzing the status of tourism in order to restore it during post-conflict period is extremely relevant and requires detailed study.

Research methods. The methodological foundations for the study of conflicts are poorly developed in contemporary social geography. The high level of objective complexity of this research is connected with the fact that at one and the same time methods of social geography, political science, conflict science, sociology, political economy, economics, philosophy, cultural studies, anthropology, psychology, and marketing are used, since the object of research is at the junction of sciences, that is, has an interdisciplinary character. Therefore, most of the existing works are designed by political scientists, sociologists, psychologists.

In conclusion, the issue of developing a methodological tool for investigating the impact of the conflict on tourism development has not been studied in detail, but it needs to be done as soon as possible. This is primarily due to changes that have taken place recently in the country and the lack of readiness of the 
tourist industry to work in a conflict situation. Therefore, this study is a very important task of social geography.

The need for a holistic description of the factors contributing to the emergence of conflicts, their drivers and participants, the prediction of the occurrence of conflict actions and measures to prevent them, in order to preserve and develop tourism, requires a problem-oriented approach.

The philosophical basis of socio-geographical study is a dialectic that examines phenomena in the process of development and interconnection. The theoretical and methodological basis of the research is the fundamental provisions of the theory of social geography.

The most important element in the study of conflicts, predicting their possible occurrence and warning is political marketing. Political marketing is a young branch of knowledge that emerged from the depths of classical marketing.

Armed with the classic marketing tools in the field of market study, political marketing has improved it, enriched by various methods of political science, sociology, anthropology and psychological research. There is a need for a comprehensive, deeper, and thorough study of political processes. "Every social process or state," wrote G. Zymmel, "which we make our object, is a definite phenomenon and, consequently, is the result of the action of innumerable deeper partial processes. Since the same actions may have their source in very different causes, it is possible that precisely the same phenomenon will be caused by completely different complexes of forces, which, combined in one point for the same action, in its further development, going beyond its boundaries, take completely different forms again"(Zymmel, 1996).

«Forecasting,» says R. Dautt, «is called causal (causative) modeling,» is an attempt to predict a behaviour called a dependent variable, by analyzing its causes, which are called independent variables (Daft, 2002). Precise forecasting is the main goal of the study, because we need to know how tourism will develop in the post-conflict period.

This report uses detailed analysis, a technique was used that combines the philosophical and general scientific principles that serve the methodological principles of scientific research. In this research analytical, statistical, comparative-geographical and historical methods were used.Thus, the method of time series was used to identify the dynamics of tourism growth and its decline due to conflict. In order to track the transformational changes in tourism, the monitoring organization method deserves attention. The tasks of identifying negative changes in the structure of tourism have been helped by statistical methods of research. Using sociological research methods, the analysis of the state of tourism was carried out in order to solve problems related to the identification of factors of a conflict character.

In order to carry out a geographic analysis of the place of tourism in Luhansk region in the allUkrainian rating, on the basis of official statistics, the main indicators were calculated reflecting the state of tourism for the beginning of the XXI century.

As was mentioned, official statistics from different sources have significant differences, which is caused by different methodological bases of accounting, and also by the significant shadow economy turnover in the industry. It is currently impossible to accurately determine the volumes of the market for tourist flows.

It should be noted that today the existing form of state statistical reporting is obsolete, informatively imperfect, and does not take into account current needs. Based on this, it is impossible to isolate the share of consumer goods and services taken up by the tourism industry for any particular period. Today tourism is not defined as a separate type of economic activity in the international classifier of economic activities and the National Classifier DK 009: 2010.

One of the important problems is the unification of statistical surveys of indicators of the tourism industry between different state bodies or public organizations. For example, the State Service for Tourism and Resorts, has counted all foreign citizens who arrived in the territory of Ukraine as tourists, regardless of the true purpose of their visit. The State Statistics Service of Ukraine names only those foreigners as tourists who officially took advantage of tourist services.

A similar situation regarding the discrepancy between statistical data and between different state bodies and agencies leads to a distortion of the assessment of basic tourism indicators and gives the chance to unscrupulous market participants to organize shadow turnover in the tourism industry. All this causes a slowdown in the growth of the domestic tourism industry and a lack of understanding of its importance in the context of the development of the national economy as a whole.

The peculiarity of the above analysis is that up to 2014 all the territory of Luhansk region was involved in the statistical data, while from that year to the present the data are given without taking into account the territory beyond the control of the Ukrainian government. 
Achieved results. Tourism is one of the most profitable branches of the world economy and is gradually becoming a priority sphere of national development. However, in Ukraine, it faces many problems on the path to its development.

Consideration of the main obstacles to tourism development is directly related to the domestic economic problems of the country's sustainable development. Indeed, for all the complexities and contradictions inherent in the conflict period, the country's sustainable development must testify the viability of the idea, its conformity to national interests and priorities.

According to the world rating of the number of foreign tourists, compared to the data of 2013,
Ukraine has lost half of its position, dropping from 14 th to $25^{\text {th }}$ place, the number of visitors falling from 24,671 thousand people to 12,721 thousand people. According to the State Statistics Service in 2016, the regions of Odessa, Kyiv, Lviv and Ivano-Frankivsk were developed tourism regions as before. Thus, 43,355 tourists were served in Odessa region, in Kyiv region and Kyiv - 1,825,652, in Lviv - 138,048, and in Ivano-Frankivsk regions - 74,919. Totally in Ukraine 2,250,997 people were serviced (Statistical Yearbook of Ukraine, 2016) (Table 1).

Unfortunately, in 2017, Ukraine was not ranked in the list of countries attractive for tourism; its leaders were Spain, France and Germany (World Tourism Organization, 2017).

Table 1. Distribution of tourists serviced by tour operators and travel agents according to the purpose of trip and types of tourism in 2016 by region, persons

\begin{tabular}{|c|c|c|c|c|c|c|c|c|}
\hline & \multirow[b]{2}{*}{$\begin{array}{l}\text { Served tour- } \\
\text { ists, all }\end{array}$} & \multicolumn{6}{|c|}{ Including the purpose of travel } & \multirow{2}{*}{$\begin{array}{l}\text { Of these, } \\
\text { child re } \\
\text { are } 0-17 \\
\text { years old }\end{array}$} \\
\hline & & $\begin{array}{l}\text { service, busi- } \\
\text { ness, training }\end{array}$ & leisure, rest & treatment & sport & special & Others & \\
\hline Ukraine & $2,250,107$ & 176,230 & $1,902,900$ & 79,412 & 2,982 & 768 & 87,815 & 199,956 \\
\hline \multicolumn{9}{|l|}{ Regions } \\
\hline Vinnitsa & 11,348 & 5 & 11,321 & 22 & - & - & - & 1,681 \\
\hline Volyn & 16,525 & 6 & 15,648 & 871 & - & - & - & 1,448 \\
\hline Dnipropetrovsk & 24,296 & 207 & 23,037 & 918 & 134 & - & - & 4,143 \\
\hline Donetsk & 9,753 & 69 & 9,240 & 56 & 7 & - & 381 & 1,550 \\
\hline Zhytomyr & 2,597 & 2 & 2,595 & - & - & - & - & 398 \\
\hline Zacarpathiy & 6,705 & 76 & 6,532 & 12 & - & - & 85 & 1,267 \\
\hline Zaporozhye & 21,016 & 278 & 19,789 & 949 & - & - & - & 2,458 \\
\hline Ivano-Frankivsk & 74,919 & - & 72,273 & 334 & - & - & 2,312 & 3,587 \\
\hline Kyiv region & 11,001 & 6 & 10,815 & 151 & 7 & 22 & - & 1,763 \\
\hline Kirovograd region & 2,181 & 20 & 2,137 & 24 & - & - & - & 315 \\
\hline Luhansk & 577 & 4 & 535 & 38 & - & - & - & 40 \\
\hline Lviv & 138,048 & 658 & 74,267 & 61,645 & 406 & 127 & 945 & 9,291 \\
\hline Mikolaiv & 5,575 & 2 & 5,561 & 10 & 2 & - & - & 610 \\
\hline Odesa & 43,355 & 12,721 & 30,002 & 35 & 74 & 276 & 247 & 2,854 \\
\hline Poltava & 3,383 & 123 & 3,076 & 122 & 22 & 40 & - & 689 \\
\hline Rivne & 4,266 & 3 & 4,247 & 16 & - & - & - & 595 \\
\hline Sumy & 5,665 & 1,559 & 3,862 & 27 & - & - & 217 & 283 \\
\hline Ternopol & 2,934 & 41 & 2,764 & - & 129 & - & - & 914 \\
\hline Kharkiv & 19,122 & 89 & 18,529 & 455 & 12 & 37 & - & 2,386 \\
\hline Kherson & 4,647 & 2 & 2,987 & 1,646 & - & - & 12 & 544 \\
\hline Khmelnitsky & 9,319 & 10 & 8,782 & 24 & - & - & 503 & 1,088 \\
\hline Cherkassy & 2,624 & 1 & 2,542 & 63 & - & - & 18 & 566 \\
\hline Chernivtsi & 11,731 & 185 & 11,309 & 29 & 51 & 1 & 156 & 1,275 \\
\hline Chernihiv & 3,869 & 4 & 3,861 & 4 & - & - & - & 340 \\
\hline Kyiv & $1,814,651$ & 160,159 & $1,557,189$ & 11,961 & 2,138 & 265 & 82,939 & 159,871 \\
\hline
\end{tabular}

${ }^{1}$ Excluding the temporarily occupied territory of the Crimea Autonomous Republic, the city of Sevastopol and parts of ATO zone. Source: done by the author on the basis of (Statistical Yearbook of Ukraine, 2016) 
So, it can be noted that the favourable geographical location, attractive tourist resources, the presence of potential tourist sights, developed tourist infrastructure and skilled labour resources do not guarantee the successful development of tourism. In fact, a paradoxical situation arises when countries with less attractive natural and cultural-historical backgrounds than Ukraine have a significantly higher ranking of tourist attractiveness in the world market for tourist services. It is a fact that in the conditions of globalization, in order to increase the rating of tourist attraction, it is necessary not only to monitor the indicators of tourism development, but to use actively the levers of geo-differentiation and positioning of the tourist space to reflect the distinctive features of national tourist product offer.

Analyzing the above factors which are hindering the development of tourism in Ukraine and the formation of a competitive national tourism product, may include:

insufficiently developed tourist infrastructure in the regions; insufficient awareness of the tourism potential, its impact on the regional economy;

insufficient attention of local and regional authorities to tourism in their territories;

low investment and business activity in organizing activities that can attract local and foreign tourists; shortage of skilled personnel in the field of tourism;

lack of information on events in the regions and the low efficiency of the systems for promoting tourist product to the market;

high travel prices for major tourist destinations;

most important for Ukraine in the present and immediate future: fear of terrorism, crime; unstable political situation (Fig. 1).

According to market research, conducted by the World Tourism Organization for tourist services, the reasons for the decline of Ukrainian tourism are as follows:

neglect of experience of international tourism development;

lack of consistent state policy in the industry; ineffective government activity in the field of tourism;

lack of proper conditions for the development of tourism, tax and financial incentives by the state to export tourism services and domestic tour operators;

unsatisfactory work on the formation and strengthening of Ukraine's tourist image, development and promotion of the national tourism product in the international and domestic markets.

Signs and effects of decline: decrease in the number of tourists in comparison with the indicators for 2012-2013;

a significant reduction in the share of tourism in the country's GDP;

falling incomes from tourist services and hotel services, tourist fees, currency revenues from exports of tourist and hotel services, investments in tourist infrastructure, jobs (Site of the World Tourism Organization, 2018).

Today, Ukraine needs significant investment in tourism development, first of all, in tourism infrastructure, which is one of the main reasons preventing the growth of the tourist sector due to its obsolete nature and the inability to meet the needs of potential consumers. But, in recent years there has been a decline in investment in the tourism industry.

The share of tourism in the Ukrainian GDP is only $2 \%$, and in developed countries - this figure reaches $8 \%$ (Statistical Yearbook of Ukraine, 2018).In our country, tourists arrive mainly from Germany, the United States, Great Britain, China and Japan (Fig. 2).

Territorial hardships, economic problems and political uncertainty have led the tourist industry of Ukraine to a disastrous state: in 2014-2015 the tourism market fell by $40 \%$ (Tourist activities in Ukraine, 2017).

In the structure of income from tourism in developed countries, domestic tourism gives 80 $90 \%$, and on average in the world - more than $72 \%$. In Ukraine, about 64\% (Figures 3 and 4) (UNWTO, 2018).

Domestic tourism in Ukraine is underdeve-loped and needs state support.

About six million people make more than 10 million tour-trips within the country. During 2001-2011, investment in the hotel and restaurant sector increased from 469 to 4,908 million US dollars, a 10.5 times increase. During 2011-2014, capital investment in tourist accommodation and catering decreased to 1.5 bln. UAH. $70-80 \%$ of tourist flow is provided by foreign tourists and only $20-30 \%$ by domestic tourists. During 2000-2014, the share of domestic tourists in the market tended to decrease, and even a sharp decline in entry tourism in 2014 did not significantly affect the structure of tourist flows, which may indicate an insufficient development of domestic tourism in Ukraine (Tourist activities in Ukraine, 2017).

As a result of the analysis, it turned out that during the period of stable development of tourism, namely in 2006-2008, Luhansk region took one of the leading places among 25 regions of Ukraine (Table 2).

During 2008, increase in the number of outbound tourists was observed in Ukraine, and the share of 


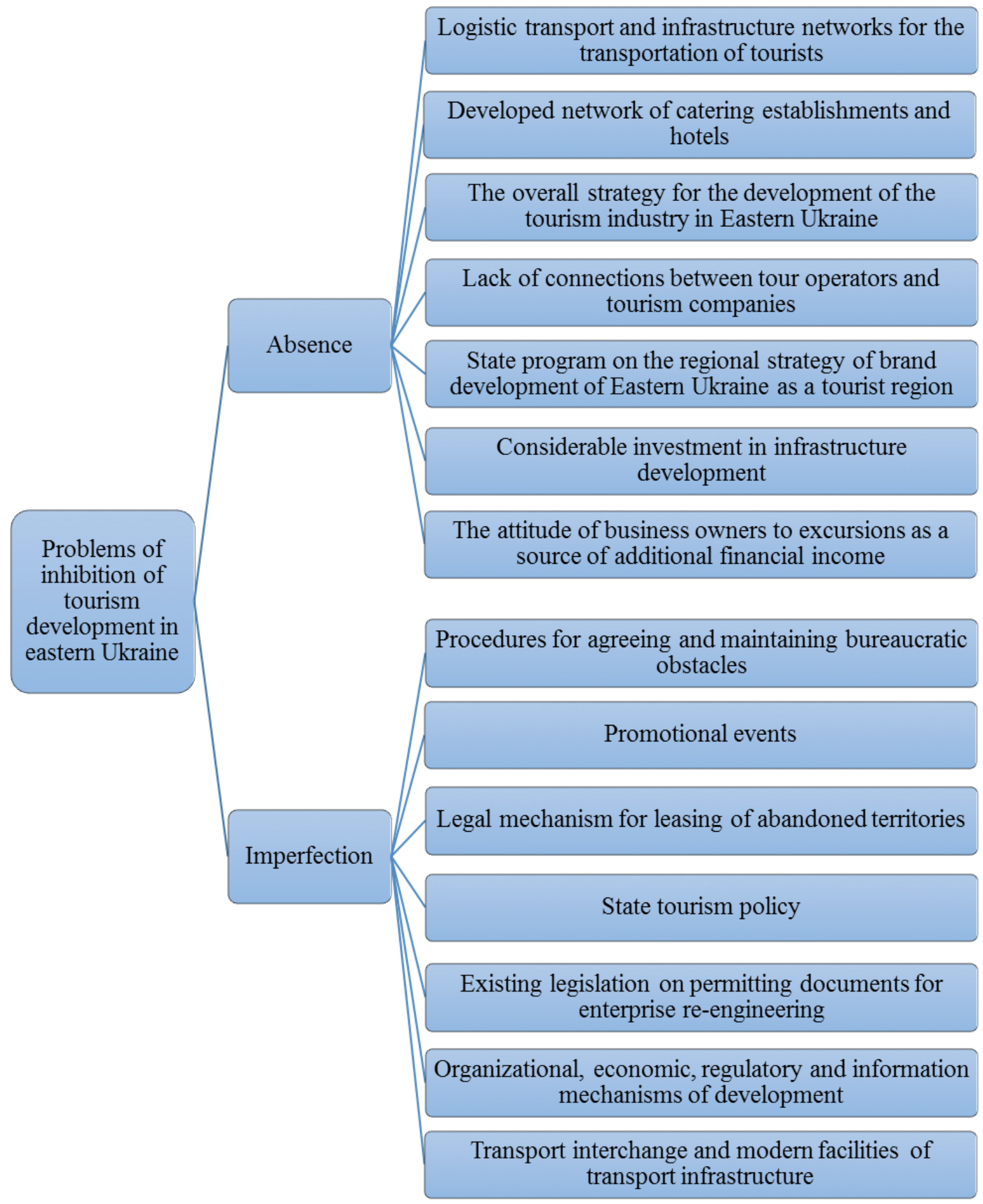

Fig. 1. Factors hindering the development of tourism in Ukraine Source: done by the author on the basis of (Ukrainian tourism)

Luhansk region was $50 \%$ from the total (The statistical bulletin «Tourism in Luhansk region (2001-2006)» 2007).

Due to the increased income in Luhansk region, the number of outbound tourists grew rapidly. According to the Main Department of Statistics in Luhansk region, the average wage in all districts of the region was higher than the minimum living wage for an able-bodied person (UAH 669), however, only in 10 of the districts do the wages exceed the average in the region: Rovenky - 2745 UAH, Sverdlovsk 2427 UAH, Krasnodon - 2217 UAH, Alchevsk - 2027 UAH, Perevalsky district - 2021 UAH, Antratsit - 2005 UAH, Lutuginsky district - 1988 UAH, Krasny Luch - 1873 UAH., Lisichansk - 1856 UAH., Pervomaisk - 1855 UAH (Luhansk region in figures in 2008, 


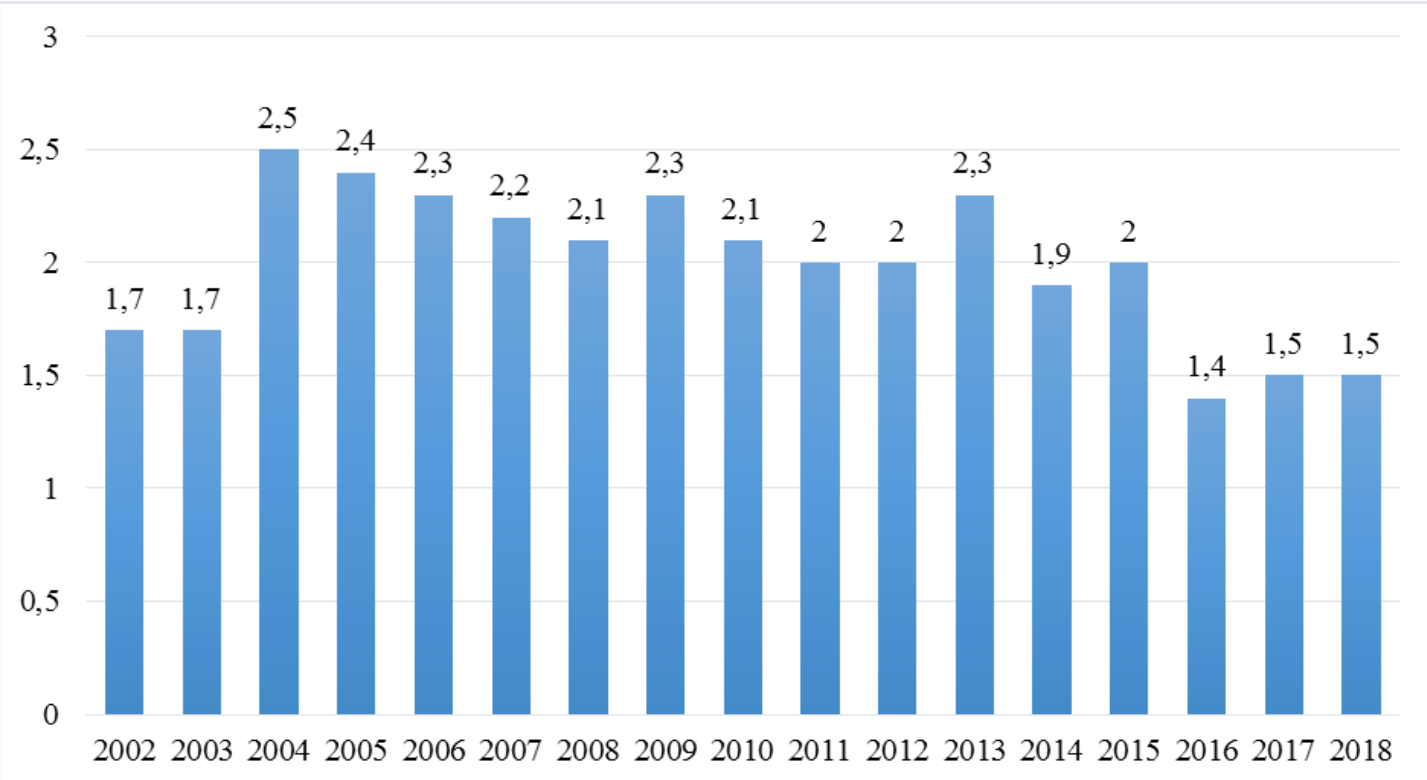

Fig. 2. Total contribution from tourism to GDP of Ukraine, \%Ukrainian tourism Source: done by the author on the basis of (Statistical Yearbook of Ukraine, 2018)

2009a). Also, in 2008 the growth of the number of outbound tourists was due to an increase in the types of tourist products and the quality of tourist services.

The lowest rate of entry tourism was recorded in 2005 and amounted to 17 people. In 2008, this figure
Dynamics of tourist activity in Ukraine and Lugansk region is presented in Fig. 5.

An analysis of the size of payments to the budget by subjects of tourism activity showed an increase of almost 4 times and amounted to 2,081 thousand

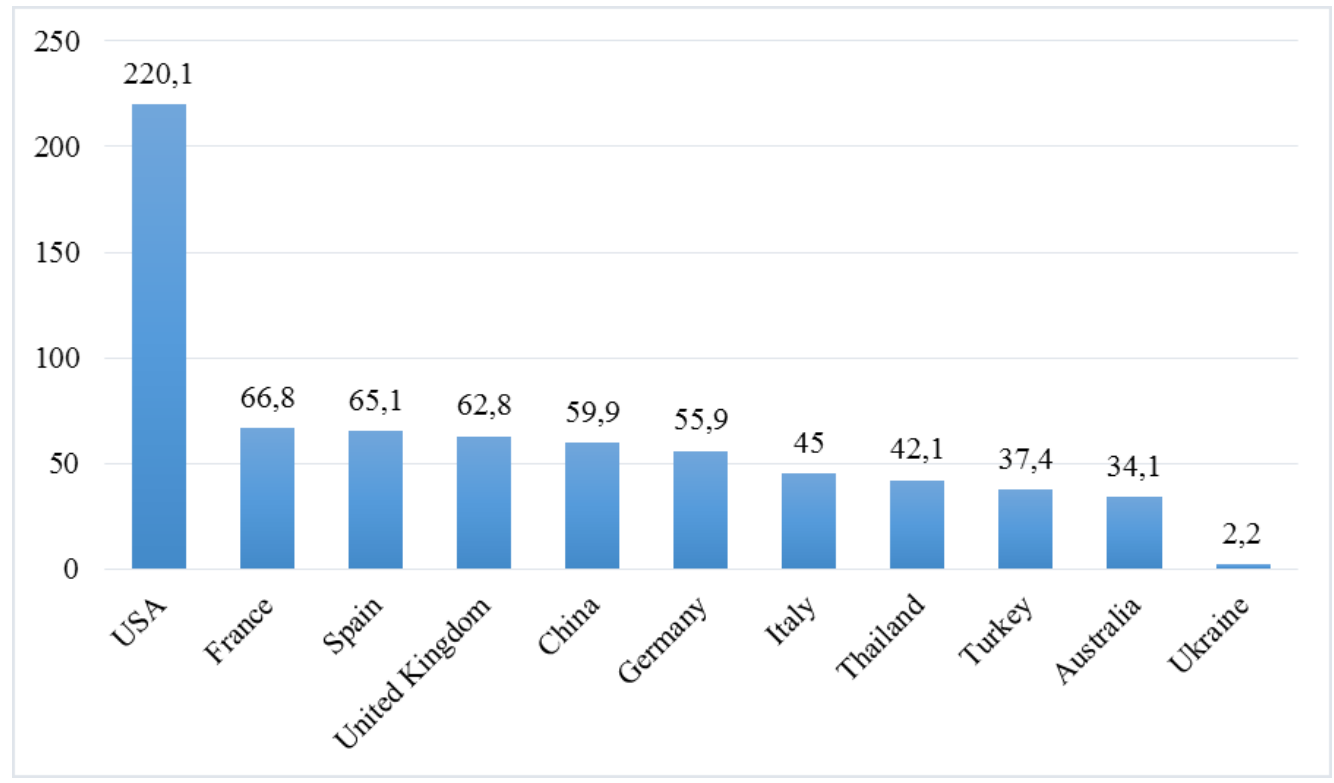

Fig. 3.Tourism Profit Rating, billion dollars USA

Source: done by the author on the basis of (UNWTO, 2018)

increased 7-fold and amounted to 126 people. After analyzing this indicator in other regions of Ukraine, it was found that Zhytomyr region ranked last in the overall ranking, with 56 people. The development of excursion activities in the Luhansk region has decreased by 18.9 thousand people, or $47 \%$, compared to 2007 (Main Department of Statistics in Luhansk region, 2018b).
UAH against 2007. Such changes in payments to the budget can be explained by an increase in the number of registered entities of tourism activity in Luhansk region (Luhansk region in figures in 2008, 2009b).

Luhansk region had considerable economic potential before the conflict and was one of the five most significant industrial and economic regions in Ukraine (Lugansk Regional State Administration, 


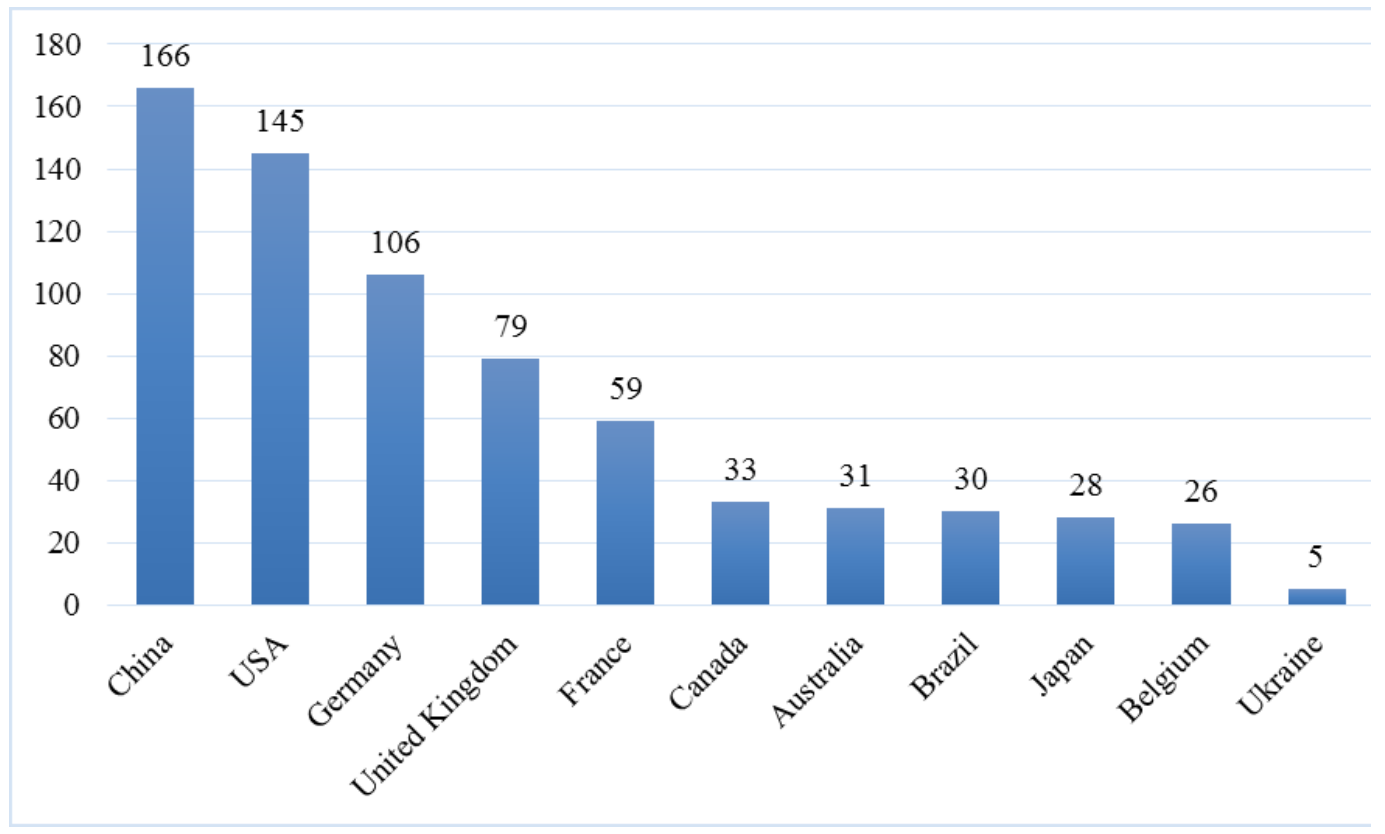

Fig.4. Tourism spending rating, billion dollars USA

Source: done by the author on the basis of (UNWTO, 2018)

Table 2. Rating of Luhansk region on the main indicators of tourism development in Ukraine for 2006 - 2008

\begin{tabular}{|c|c|c|c|}
\hline Key Indicators & 2006 & 2007 & 2008 \\
\hline \multicolumn{4}{|l|}{ 1. Number of enterprises providing services } \\
\hline Units & 75 & 96 & - \\
\hline Share in $\%$ & 2.5 & 2.5 & - \\
\hline 2 Total tourists served & 50,881 & 59,096 & 53,279 \\
\hline Share in $\%$ & 1.4 & 1.11 & - \\
\hline Rating & 17 & 16 & - \\
\hline 2.1. Entry & 162 & 158 & 126 \\
\hline Share in $\%$ & 0.01 & 0.02 & - \\
\hline Rating & 25 & 25 & - \\
\hline 2.2. Departure & 10,761 & 14,088 & 15,487 \\
\hline Share in $\%$ & 0.8 & 0.85 & - \\
\hline Rating & 11 & 12 & - \\
\hline 2.3 Domestic & 39,958 & 44,850 & 37,666 \\
\hline Share in $\%$ & 2.1 & 1.49 & - \\
\hline Rating & 16 & 14 & - \\
\hline 3. Number of excursion tourists & 30,993 & 39,984 & 21,022 \\
\hline Share in $\%$ & 1.8 & 1.67 & - \\
\hline Rating & 13 & 9 & - \\
\hline 4. Scope of service provision (thousands uah) & 37,505 & 12,825 & . \\
\hline Share in $\%$ & 1.0 & 0.24 & - \\
\hline Rating & 12 & 25 & - \\
\hline 5. Payments to the budget (thousands uah) & 761 & 555 & 2081 \\
\hline Share in $\%$ & 0.6 & 0.52 & - \\
\hline Rating & 23 & 23 & - \\
\hline 6. Average number of employees & 245 & 272 & 283 \\
\hline Share in $\%$ & 1.1 & 1.2 & - \\
\hline Rating & 19 & 19 & - \\
\hline
\end{tabular}

Source: done by the author on the basis of (The statistical bulletin “tourism in Lugansk region (2001-2006)", 2007). 


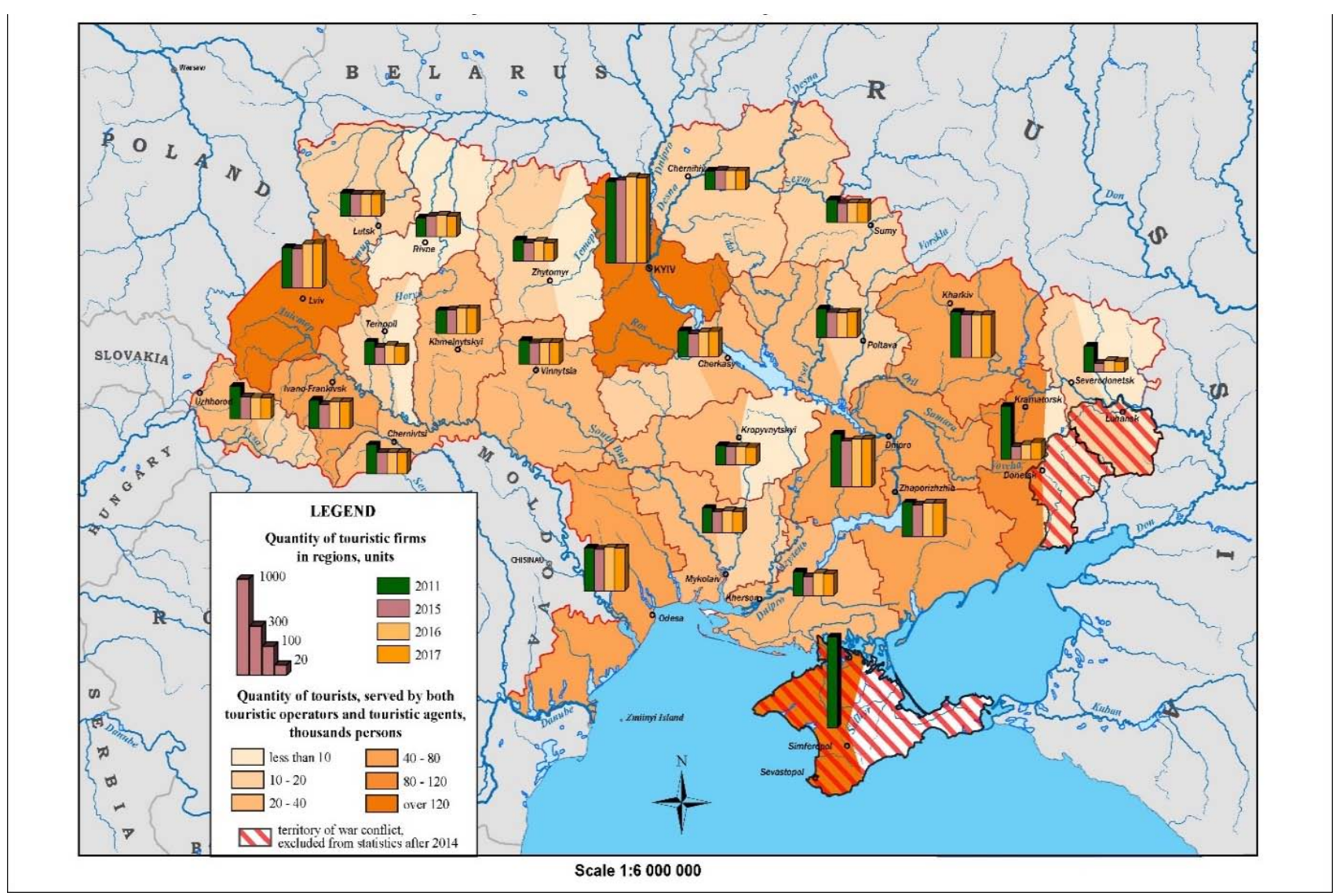

Fig. 5. Dynamics of tourist activity of Ukraine

Source: done by the author on the basis of (Tourist activities in Ukraine, 2017).

2018). As a result of the conflict, the tourism industry in the region has declined and the situation has changed negatively. Historically, Luhansk region developed as an industrial land. However, in the pre-conflict period in the eastern regions, structural changes in the economy began, including the formation of regional tourism (Zavarika, 2018). The conflict has brought a promising direction for economic development of the eastern regions of Ukraine to the brink of permanent disappearance.

For Luhansk region, tourism development is relevant, because it can improve the socioeconomic situation. The region has favourable natural and climatic conditions, flora and fauna, mineral water springs and other resources for the development of tourism (Zavarika, 2018).

As we can see from Table 3 below, Luhansk region lost its position in tourism activity and by 2017 occupied the last (24th) place among the regions of Ukraine. Among the outsiders in Ukraine are Donetsk, Kirovograd, Zhytomyr, Ternopil, and Chernihiv regions (Main Department of Statistics in Luhansk region, 2018d). Luhansk region in 2011 ranked 11th by the number of subjects of tourism activity among the regions of Ukraine, which was less than $3 \%$ of the overall Ukrainian total.
Since 2015 there has been a rapid decline in the number of tourists, the region has taken the last place for this indicator and, despite a small amount of growth, continues to occupy this low position. By 2017 , this figure was $0.5 \%$ in absolute terms.

In 2011 The number of tour operators in the region was too low and amounted to only $0.28 \%$, and at this time they are completely absent (Main Department of Statistics in Luhansk region, 2018e).

The number of travel agents in the pre-conflict period was quite high, the region ranked 9th in the country by this indicator, which was $2.8 \%$. Now the situation has not changed in favour of the region, but it can be stated that there has since been a slow growth in the number of travel agents, so in 2017 their number was 17 , or $0.6 \%$ of the total.

With regard to the indicator of the number of subjects carrying out excursion activities in the region even during the pre-conflict period the situation was difficult, they did not function at all, now the situation has unfortunately not changed for better (Main Department of Statistics in Luhansk region, $2018 \mathrm{~g}$ ). Sightseeing activity is very important for the formation of a positive tourist image and the attractiveness of the territory. Unfortunately, we did not have time to form this in the pre-conflict period, 
Table 3. Tourist activity of Luhansk region

\begin{tabular}{|c|c|c|c|c|c|}
\hline Key indicators & 2011 & 2015 & 2016 & 2017 & 2018 \\
\hline 1.Number of subjects of touristic activity & 94 & 11 & 19 & 17 & 17 \\
\hline Share in $\%$ & 2.26 & 0.34 & 0.54 & 0.49 & 0.49 \\
\hline Rating & 11 & 24 & 24 & 24 & 24 \\
\hline 2. Number of tour operators & 2 & - & - & - & - \\
\hline Share in $\%$ & 0.28 & - & - & - & - \\
\hline Rating & 24 & 24 & 24 & 24 & 24 \\
\hline 3. Number of travel agents & 92 & 11 & 19 & 17 & 17 \\
\hline Share in $\%$ & 2.80 & 0.43 & 0.67 & 0.60 & 0.60 \\
\hline Rating & 9 & 24 & 24 & 24 & 24 \\
\hline 4. Number of subjects carrying out excursion activities & - & - & - & - & - \\
\hline Share in $\%$ & - & - & - & - & - \\
\hline Rating & 24 & 24 & 24 & 24 & 24 \\
\hline $\begin{array}{l}\text { 5. Number of tourists serviced by tour operators and travel } \\
\text { agents }\end{array}$ & 15,558 & 939 & 1,896 & 2,825 & 6,261 \\
\hline Share in $\%$ & 0.84 & 0.04 & 0,07 & 0.10 & 0.13 \\
\hline Rating & 18 & 24 & 24 & 24 & 24 \\
\hline 6. Number of tourists serviced by tour operators & 1,199 & - & - & - & - \\
\hline Share in $\%$ & 0.08 & - & - & - & - \\
\hline Rating & 18 & 24 & 24 & 24 & 24 \\
\hline 7. Number of tourists serviced by travel agents & 14,359 & 939 & 1,896 & 2,825 & 6,261 \\
\hline Share in $\%$ & 1.80 & 0.10 & 0.24 & 0.33 & 0.13 \\
\hline Rating & 11 & 24 & 24 & 24 & 24 \\
\hline
\end{tabular}

Source: done by the author on the basis of (Tourist activities in Ukraine, 2017)

and now a considerably greater amount of work will of the region during the post-conflict period. need to be done to convince a potential tourist that there is something to look at in Luhansk region. So this is one of the main tasks of tourism development
Indicators of the number of tourists served by tour operators and travel agents are clearly depicted in Fig. 6. The highest indicator of the number of

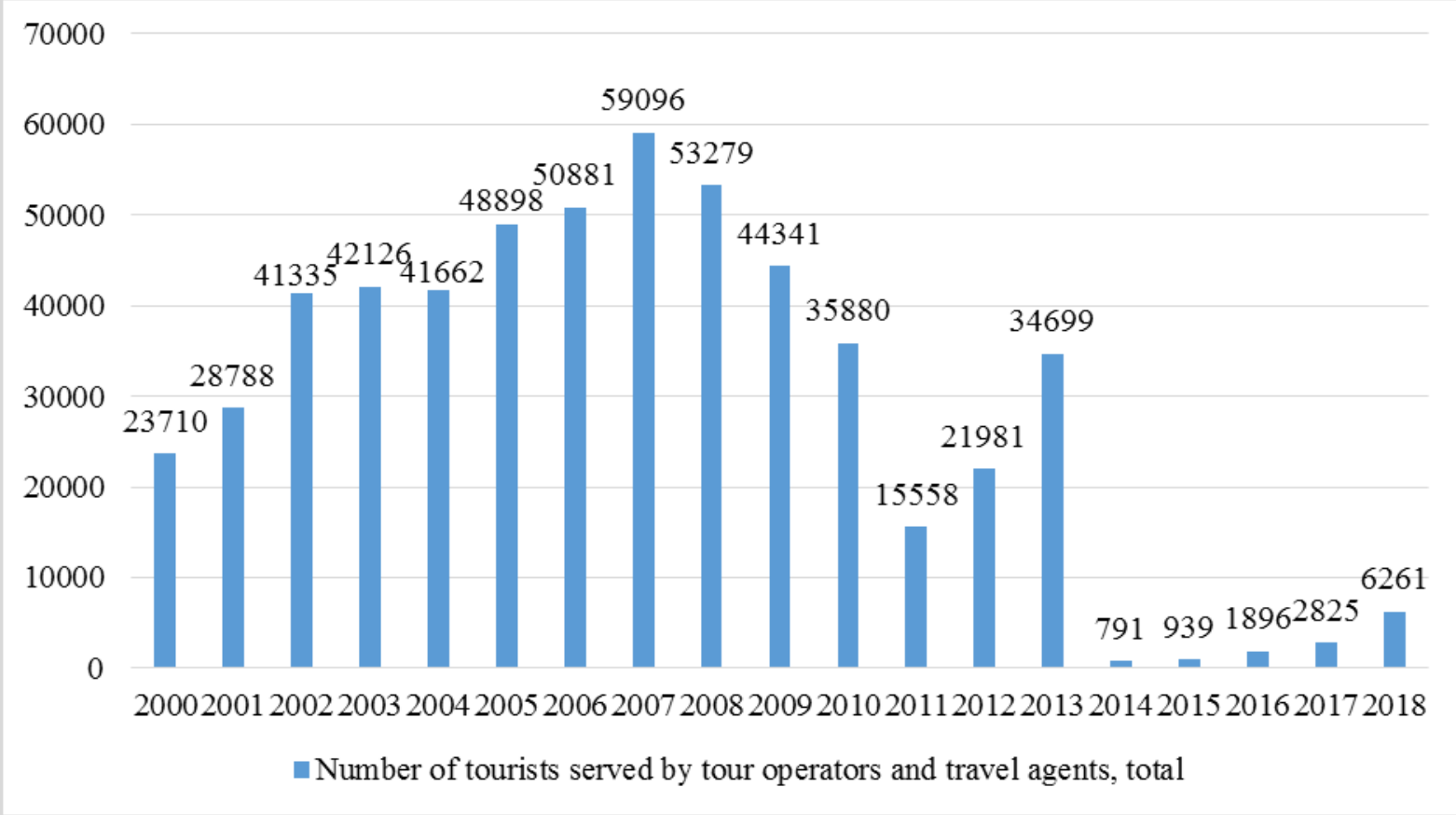

Fig. 6. Number of tourists serviced by tour operators and travel agents (in total)

Source: done by the author on the basis of (Main Department of Statistics in Luhansk region 2018h) 
tourists in the region was noted in 2007. After 2007 the level varied depending on various economic and geographical factors. And from 2014, the crisis period associated with the conflict in the region begins when the number of tourists was the lowest in the history of tourism development in the region.

It will also be interesting to analyze tourists by type, namely: foreign tourists, local tourists in Ukraine who traveled abroad and domestic tourists, which is presented in Fig. 7. It turned out that the number of foreign tourists has always been low, and during the conflict they have been completely absent. The number of local tourists in Ukraine who traveled abroad and domestic tourists was the highest in the region during 2006 to 2013, which we consider to be the most successful for the entire period of development (Main Department of Statistics in Luhansk region, 2018i).

The decrease in the number of tourists in the region is due to the decision of the Luhansk Regional State Administration to ban tourist activity in 2014 on account of the safety of tourists (Zavarika, 2018). Also that after 2014 the statistics only take into account

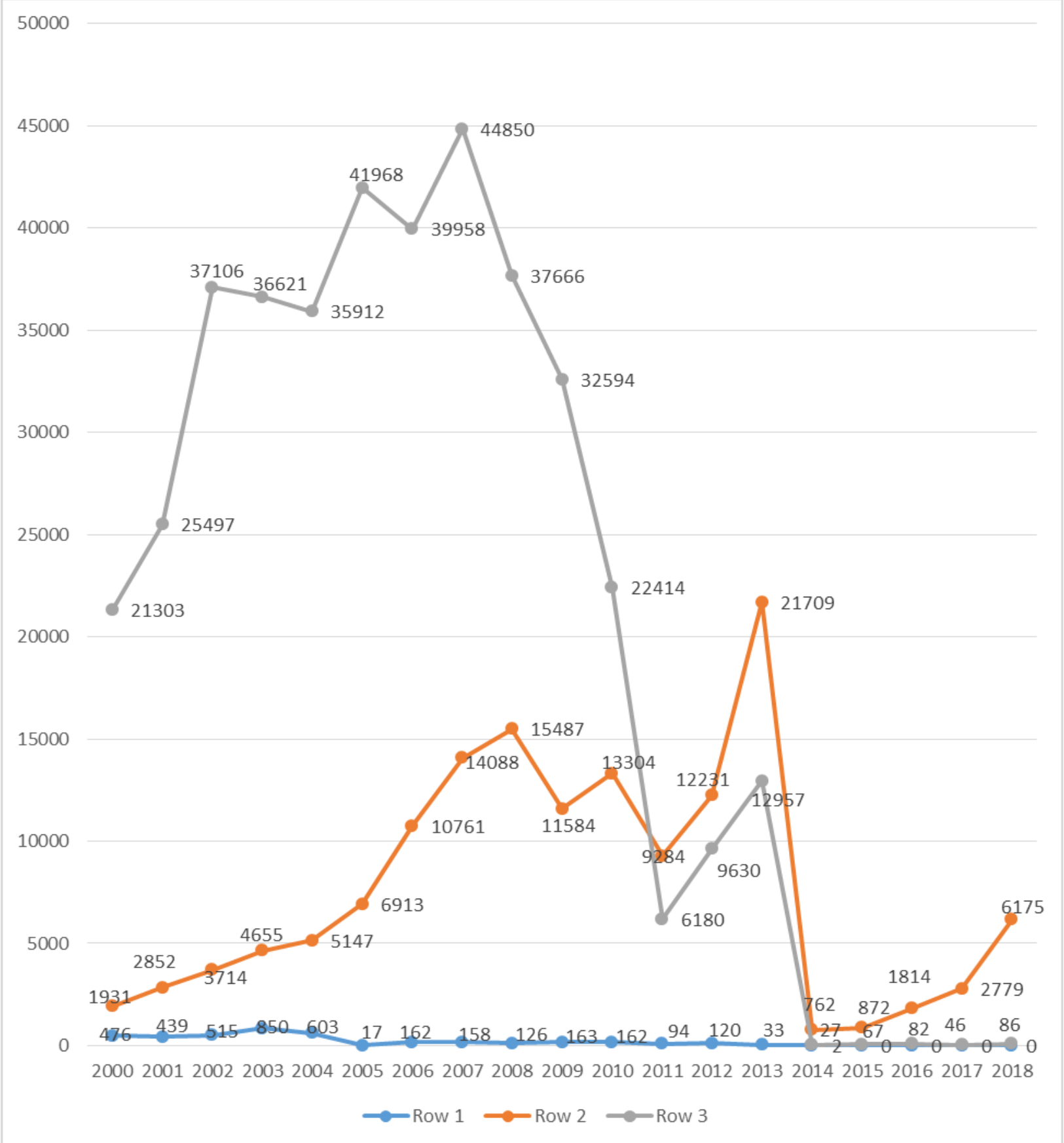

Fig. 7. The number of tourists by type: Series 1-foreign tourists, series 2- local tourists who traveled abroad and series 3- domestic tourists

Source: done by the author on the basis of (Main Department of Statistics in Luhansk region 2018j) 
information concerning the territory under the control of the Ukrainian government.

It is important to note that the potential of tourism opportunities in the Luhansk region is quite rich. Each district of Luhansk region has a huge tourist potential and a wide range of tourist resources, historical and cultural heritage, and traditions of hospitality (Zavarika, 2018).

During 2017, the Luhansk Regional State Administration implemented measures for inventory of available tourist resources, developed and updated a Tourist Passport of the region, which includes 606 tourist facilities, 25 hotels, 11 estates, 27 travel agents (Luhansk regional state administration, 2018a).

Among the attractions there are 152 religious institutions, 21 museums, 1 landscape park, 95 nature reserves of Luhansk region, 1 cave, 19 springs, 14 recreation complexes, 20 recreation centers, 11 recreation and entertainment establishments, 3 cultural leisure establishments, 194 monuments, and 30 objects of tourist activity which at the moment do not function due to the ongoing military action or the need to be restored (Luhansk regional state administration, 2018b).

Conclusions. The analysis of statistical data allows us to assert that in the pre-conflict period, attention was not paid to tourism in the region. Tourism in Luhansk region was not perceived as a strategic sphere, the development of which would contribute to the revitalization of the social situation and economic growth. This was due to its low growth rate, which was manifested in abandoned infrastructure, a relatively small number of hotels, lack of legislative guarantees of the activities of local tour operators. As a result, the number of tourists visiting the region during the pre-conflict period was relatively small compared to other regions. The conflict between 2014 and 2018 only deepened the existing problems and contributed to the emergence of new ones.

The conflict in the Donbass negatively affected the development of the tourism industry in the region. First of all, it caused important negative economic changes that completely changed the "face" of the region. From 2014, the socioeconomic model in Luhansk region was completely destroyed and the main task of the scientists in the post-conflict period should be the creation of a new system, which, according to the basic parameters, will differ from the previous one. Tourism in the post-conflict period may become, if not a "locomotive" of change, an important component of it. All efforts are aimed at ensuring that the tourist industry becomes one of the leading ones in the post-conflict era.
Prospects for further research are the identification of measures for the development of tourism in Luhansk region by the local authorities and the geographical study of similar situations in different countries of the world.

\section{References}

Averin, A., 2017.Derzhavne rehuliuvannia demohrafichnykh ta mihratsiinykh protsesiv v Rosiiskii Federatsii. [State regulation of demographic and migration processes in the Russian Federation]. M., 125 (in Russian).

Beidik, O., Koroma, N., Syrovets, S., 2016. Svitovyi turistychnyi rukh: stan, tendentsii ta perspektyvy rozrobky v konteksti shchodennoho heopolitychnoho zahrozu. [World tourism movement: status, trends and development prospects in the context of the daily geopolitical threat] Geography and tourism, 37, 3-15 (in Ukrainian).

Chudoba, T., 1998.Wprowadzenie do teorii turystyki.[Introduction to the theory of tourism] Warszawa, 112(in Polish).

Daft, R.,2002. Menedzhment.[Management] SPb, 802(in Russian).

Dahrendorff, R., 2002. Suchasnyi sotsialnyi konflikt. Narys pro polityku svobody: ese.[Modern social conflict.Essay on the politics of freedom: essay]. M., 270 (in Russian).

Goeldner, Charles, R., Ritchie, J., 2002. Turyzm: pryntsypy, praktyka, filosofiia.[Tourism: Principles, Practices, Philosophies]. N.Y., 512 (in English).

Huntington, S., 1996.Zitknennia tsyvilizatsii [The Clash of Civilizations][Online], Available:

https://www.litres.ru/semuel-hantington/stolknoveniecivilizaciy/chitat-onlayn/(in Russian).

Kaldor, M., 2001. Novi ta stari viiny: orhanizovane nasylstvo v hlobalnii eri. [New and Old Wars: Organized Violence in a Global Era]. Cambridge, 132 (in English).

Lugansk region in figures in 2008, 2009.Derzhavnyi komitet statystyky Ukrainy, Luhansk [State Committee of Statistics of Ukraine, Lugansk].Heads. exercise statistics from Lugansk Region(in Ukrainian).

Lugansk regional state administration, 2018. [Online], Available:http://loga.gov.ua/(in Ukrainian).

Lyubitseva, O., Zaleschyk, V., 2012. Recreational and tourist zoning of Lugansk region. [Rekreatsiinoturystychne raionuvannia Luhanskoi oblasti]. Geography and tourism. Vip. 22, 161-167 (in Ukrainian).

Main department of statistics in Luhansk region,2018. [Online], Available: http://www.lg.ukrstat.gov.ua/ (in Ukrainian).

Myshechkin, G., Anosova, O., 2013. Donbass tourism and recreational potential: place on the Ukrainian scale, problems and prospects.[Turystsko-rekreat- 
siinyi potentsial Donbasu: mistse u zahalnoukrainskomu masshtabi, problemy i perspektyvy]. VISNYK DITB, 17, 326-329(in Ukrainian).

Poon, A.,1993. Turyzm, tekhnolohii ta konkurentni stratehii.[Tourism, technology and competitive strategies]. Oxford, 352(in English).

Spengler, O., 1998.Zanepad Yevropy. Narysy z morfolohii svitovoi istorii [The Decline of Europe. Essays on the morphology of world history]. M., 608(in Russian).

Site of the world tourism organization, 2018. [Online], Available: http://www2.unwto.org/(in English).

State service of statistics of Ukraine, 2018. [Online], Available:http://www.ukrstat.gov.ua/ (in Ukrainian).

Statistical Yearbook of Ukraine, 2016.[Statystychnyi shchorichnyk Ukrainy].State Statistics Committee of Ukraine(in Ukrainian).

The current state of legislative security for tourism in Ukraine: problems and ways for decision-making the participants of all-Ukrainian public hearing. Turististic association of Ukraine, 2018.[Online], Available:http://www.tourism.gov.ua/ publ. aspx?id=322(in Ukrainian).

The program of tourism development in the Lugansk region for 2002-2010, 2002. Lugansk Resolution of the Lugansk Regional State Administration, 743(in Ukrainian).

The statistical bulletin «tourism in Lugansk region (20012006)", 2007. LuganskVitus(in Ukrainian).

Toynbee, A., 1996. Tsyvilizatsiia pered sudom istorii [Civilization before the judgment of history]. M. SPb., 537(in Russian).

Tkachuk, L., 2016.Vplyv politychnoi nestabilnosti na ro- zvytok turystychnoho napriamku [The impact of political instability on the development of a tourist destination]. Geography and Tourism, 37, 2635(in Ukrainian).

Tourist activities in Ukraine, 2017. [Turystychna diialnist v Ukraini].Statistical collection.State Statistics Service of Ukraine, Kyiv, 90(in Ukrainian).

Zavarika, G., 2016.Teoretychne obgruntuvannia konfliktnoi modeli suspilstva [Theoretical justification of the conflict model of society]. Geography and Tourism, 37, 189-198(in Ukrainian).

Zavarika, G., Zelenko, O., 2017.Osoblyvosti rozvytku turyzmu v suchasnomu ukrainskomu Donbasi [Features of tourism development in the modern Ukrainian Donbass]. Tourism and Hospitality, 1, 39-44 (in Ukrainian).

Zavarika, G., 2018. Economic and geographical factors of tourism development of the east of Ukraine during the conflict[Ekonomiko-heohrafichni chynnyky rozvytku turyzmu skhodu Ukrainy $\mathrm{v}$ period konfliktu]. Bulletin of the University of Lviv. The series is geographical, VIP. 52, 100 109(in Ukrainian).

Zelenko, O., 2015.Perspektyvy rozvytku turyzmu Luhanskoi oblasti v umovakh viiskovo-politychnoi nestabilnosti [Prospects of tourism development of Lugansk region in the conditions of militarypolitical instability]. Scientific Herald of Mukachevo State University, 2 (4), 2, 138-143 (in Ukrainian).

Zymmel, H., 1996.Vybrane. Spohliadannia zhyttia [Favorites. Contemplation of life]. M., 671 (in Russian).

Ukrainian tourism, 2018. [Online], Available: https://www. facebook.com/Ukrainian.tourism/(in Ukrainian). 